Article

\title{
From Utopia to Dystopia: The Demise of the Revolutionary Dream in Futuristic Cuban Cinema
}

\author{
Santiago Juan-Navarro
}

check for

updates

Citation: Juan-Navarro, Santiago. 2022. From Utopia to Dystopia: The Demise of the Revolutionary Dream in Futuristic Cuban Cinema. Humanities 11: 1. https://doi.org/ 10.3390/h11010001

Received: 17 November 2021

Accepted: 17 December 2021

Published: 22 December 2021

Publisher's Note: MDPI stays neutral with regard to jurisdictional claims in published maps and institutional affiliations.

Copyright: (C) 2021 by the author. Licensee MDPI, Basel, Switzerland. This article is an open access article distributed under the terms and conditions of the Creative Commons Attribution (CC BY) license (https:// creativecommons.org/licenses/by/ $4.0 /)$.
Department of Modern Languages, Florida International University, Miami, FL 33199, USA; navarros@fiu.edu
Abstract: The armed insurrection that brought Fidel Castro to power in 1959 was one of the most influential events of the 20th century. Like the Russian and Mexican revolutions before it, the Cuban revolution set out to bring social justice and prosperity to a country that had suffered the evils of corrupt regimes. A small country thus became the center of world debates about equality, culture, and class struggle, attracting the attention of political leaders not only from Latin America but also from Africa, Asia, and Europe. Its intent to forge a model society has often been described in utopian terms. Writers, artists, and filmmakers turned to utopia as a metaphor to trace the evolution of the arts in the island from the enthusiasm and optimism of the first moments to the dystopian hopelessness and despair of the last decades. Indeed, the Cuban revolution, like so many other social revolutions of the 20th century, became the victim of a whole series of internal and external forces that ended up turning the promised dream into a nightmare tainted by autocratic leadership, repression, and political and economic isolation. Although Cuban literature has extensively addressed these issues since the collapse of the Soviet Union in 1991, it is only recently that we can find similar trends in a cinematic output that portrays Cuba as a utopia gone sour. This article examines recent films such as Alejandro Brugués' Juan de los Muertos (2011), Tomás Piard's Los desastres de la Guerra (2012), Eduardo del Llano's Omega 3 (2014), Rafael Ramírez's Diario de la niebla (2016), Yimit Ramírez's Gloria eterna (2017), Alejandro Alonso's El Proyecto (2017), and Miguel Coyula's Corazón Azul (2021). These films use futuristic imageries to offer a poignant (and often apocalyptic) depiction of the harsh paradoxes of contemporary life in Cuba while reflecting upon the downfall of utopia.

Keywords: utopia; dystopia; Cuban cinema; Cuban revolution; scpeculative fiction

Unlike classic Cuban cinema made in the shadow of the State's cultural institutions, young filmmakers use a variety of forms of speculative fiction ${ }^{1}$ to reflect on the dystopian nature of the revolution within futuristic imaginaries and apocalyptic scenarios. The way that they carry out those reflections is quite unique, given the special idiosyncrasy of Cuban cinema. In Latin America, with the sole exceptions of Mexico, Brazil, and Argentina, there has never been a solid tradition of speculative cinema that can explain the emergence and evolution of its variants in Cuba. Even in those three countries, the context of production is so different to the Cuban context that forced extrapolations do not seem appropriate to fully understand the issue at hand. Furthermore, this phenomenon is quite recent in Cuba, where it has only begun to gain traction in the 21st century, hence the absence of a critical corpus on this issue. ${ }^{2}$

Since the 1959 Revolution, cinema on the island aimed at consolidating revolutionary values. As a result, didactic and historical cinema underlying the utopian character of the revolutionary project was always favored. Although during the so-called "Golden Age" (the 1960s), political propaganda coexisted with formal experimentation, tensions soon arose that led to the institutionalization of a model that further emphasized the propaganda component and the submission of all cultural production to the State apparatus. For decades, there was a model of cinema that systematically stifled political or aesthetic dissent. Most genres and film styles associated to speculative fiction were generally looked down upon by the intellectual elite, who tended to associate them with consumer and 
entertainment culture. It was only after the creation of the Muestra de Jóvenes Realizadores (Festival of Young Directors) in 2000 that things began to change. Although political tensions have not ceased, an opening up of the formal and ideological film repertoire and a greater tolerance for new forms of expression was set in motion.

The purpose of this article is to analyze those films that have dealt with the debacle of the revolutionary utopia through speculative fictions reflecting on the social context of the island. It should be clarified that in most of the cases under study, filmmakers do not show a particular allegiance to a genre. Different varieties of speculative fiction are used rather as instruments of social, political, or aesthetic reflection. Most of these are independent productions with little circulation, which are part of a paradigm shift in the cultural currents of recent years. However, before undertaking the analysis of these works, it seems appropriate to establish the historical context from which they emerge and the relevance of the topics they examine.

\section{The Downfall of the Revolutionary Utopia}

The arrival of the modern era is marked by a peculiar dynamic resulting from various historical processes. The engine of modernity has been, in part, the rise of revolutionary utopia. The metaphysical rebellion of the philosophers of the Enlightenment led to a historical rebellion. Rebellion is born when human beings, in the name of principles such as freedom and justice, revolt against the oppression and chaos they encounter in the world around them. The rebel is one who wonders about the reasons for abuse, arbitrariness, intolerance, and tyranny. Every revolution originates from the humanistic principles of those seeking to change the world into another-one that is more just and humane.

When rebellion becomes radical, it often turns into a revolution. This occurs when it departs from its humanistic origins and becomes historical factuality, seizes power, and becomes the destiny of humanity. It raises the utopia of equality - a paradise possible only at the end of history. Until then, present generations will have to suffer restrictions that benefit the future of mankind. There has been no revolution without a dogma, a party, a slogan, a flag, and a clique of stalwarts. Their project has always been a totalitarian state, and their methods have been to indoctrinate the masses and silence dissidents. The conspirator's basement soon becomes the inquisitor's living room. The object of political action is no longer the welfare of the individual or respect for freedoms but the greatness of the State, the glory of the party, the permanence of a regime, the deification of its leader, and the continuity of the revolution in time. Every revolution, in practice, has traditionally denied the humanistic principles from which it once emerged (Merleau-Ponty 1969, p. xix).

Now, few would call the political system established in Cuba after the rise of Fidel Castro to power the "Revolution". Instead, they refer to it as "the system" or "this thing". The fall of the Berlin Wall brought serious consequences for Cuba, as the subsidies that the Socialist bloc had provided for many years ceased to exist. However, perhaps more serious than the decaying economic problems that hit the island has been the collapse of the political system, which left Cubans without financial support. The dazzling future foreseen by so many Cubans was suddenly truncated. Despite the slow and timid changes promoted by the government, frequently interrupted by repressive actions such as those recently carried out in the summer of 2021, Cuba seems to remain suspended by uncertainty, without a clearly designed government program to address a number of challenges. The inability of the State to tackle the progressive ruination of the country's material culture stands out among those challenges.

Although conditions in Havana are dire (in Centro Habana, 230 buildings collapse every year), this is a problem that affects the entire country. Young filmmakers have thoroughly documented this environmental phenomenon in its allegorical dimensions. Films such as Juan Carlos Cremata's La Época, El Encanto y Fin de Siglo (The Era and the Charm of the End of the Century, 2000), Gustavo Pérez's Sola: la extensa realidad (Alone: Extensive Reality, 2003) and Despertando a Quan Tri (Awakening Quan Tri, 2005), Alejandro Ramírez Anderson's DeMoler (Demolish 2004), Laimir Fano's Model Town (2007), 
Florian Borchmeyer's Habana: arte nuevo de hacer ruinas (Havana: The New Art of Making Ruins, 2006), Marcelo Martín's Elena (2014) and El tren de la línea Norte (The Train of the Northern Railway, 2015), and Carlos Machado Quintela's La obra del siglo (The Project of the Century, 2015) have explored the meaning of ruins and their implication in shaping national Cuban identity. ${ }^{3}$ In all these films, as well as in the films addressed below, the collapse of the Revolution's grand récit is expressed through the deterioration of material culture that embodied it. ${ }^{4}$ As a result, the desolate landscape that typically characterizes post-apocalyptic dystopic fiction spreads like a cancer throughout the whole country.

Whereas a utopia purports an ideal and perfect society, where the vast majority believe themselves to be happy and humanity appears to shine with its own light, the opposite takes places in dystopian societies. The latter condition, as often displayed in science-fiction literature and cinema, shows a dysfunctional and apocalyptic future with totalitarian societies in which alienated citizens live under the total control of a repressive power, without freedom of decision and without access to a culture that goes beyond the totalitarian principles defined by the regime. In the Cuban case, it is not necessary to resort to a distant future to represent a dystopian reality; an apocalypse on the island has already happened and continues to happen daily.

What also makes Cuba an appropriate context for these fictions is that its recent history (from 1959 to present) traces a displacement from the "good place" of utopia (eu-topos) to the "bad place" of dystopian discourse (dys-topos) (Gustafsson 2014, p. 153). The sociopolitical history of the nation has made utopia the basis of a project carried out throughout several decades of Castroism. The revolutionary project aspired, in fact, to make real the object of the utopian desires of a society that had suffered since the Spanish colonization and exploitation by foreign economic forces. Cuban history has been characterized since the years of the revolution as a futuristic story in which the imagined society coincides with political ideologies about social, economic, and cultural relations and dynamics. The realization of this utopian project could be encompassed only by means of an empty signifier, a theoretical container that includes the pragmatic expectations of a society; in this case, communism, freedom, and revolution.

With this simple expedient, many Cuban filmmakers reveal the failure of the utopian project promised by revolutionary rhetoric. In fact, after the collapse of Castro's project of an equanimous and communist society based on the New Man, Cubans are experiencing a deep ideological crisis that is reflected in art and literature and that bears the painful features of nostalgia and melancholy (Juan-Navarro 2020). The films analyzed below reflect on these issues, coming to usually (but not always) similar conclusions. While some of them offer an open critique of revolutionary utopias and their ensuing myths, criticism in others turns out to be more veiled or subtle. In some other cases, filmmakers seem uninterested in national debates or political events and decide to focus instead on more universal issues. However, even in those cases, artists are taking a political stance. In a cinemascape that for decades has been produced under the Socialist tutelage and in the context of its propaganda, moving the spotlight to imaginary worlds, barren landscapes, individual emotions, or literary universes can signal a radical break to contest the hegemonic culture in Cuba. In fact, the unprecedented interest in ethical concerns, structures of feelings, as well as in the relationship between humans and the environment can be interpreted as the beginning of a new stage in the history of Cuban cinema.

\section{Zombies in Havana}

Juan de los muertos (2011), by Alejandro Brugués, transforms and adapts the theme of the zombie to Cuban geopolitics, creating a national film that fits the parameters of the subgenre and repositions Cuban cinema in the global market. With this film, the cinema of the island joins the repertoire of the living dead with a proposal that is both conventional and new; a horror film and, at the same time, a black comedy with political overtones. In the film, the city of Havana is impregnated with the strangeness of the sinister beings, and 
the zombies become an allegory of the Cuban trauma that came with the Revolution and its final demise (Cardentey Levin 2014, p. 8).

The protagonists of the story, Juan and Lázaro, are two ordinary Cubans who are dedicated to all kinds of activities and who live looking for an opportunity to survive the horrors of modern everyday life in Cuba. Faced with the zombie invasion, Juan and Lázaro organize an anti-zombie team to defend themselves and, in the process, charge their fellow citizens for their services. "John of the Dead: We Kill Your Loved Ones" is the company's slogan and the message that customers hear on the other end of the phone. The team consists of La China (a transvestite who steals cassette decks from cars), El Primo (his hulking black friend who faints at the sight of blood), Lázaro's son, Vladi California (a playboy who dreams of Miami while scamming tourists), and Camila (Juan's daughter with a Cuban woman who lives in Spain). ${ }^{5}$

Juan de los muertos opens with a bird's-eye shot of the main character lying on a raft floating in the ocean as rain pours down. We assume that the zombie apocalypse has begun, but then we realize that this is simply a moment in modern Cuba's day-to-day life. Juan, Lázaro's friend, soon surfaces with a harpoon and declares that he has not found any fish. The friends have a drink and Lázaro asks Juan if he has ever thought about sailing on the raft to Miami. Juan responds with one of the most famous phrases of the film: "I survived Mariel, I survived Angola, I survived the Special Period, and I survived the thing that came later", ending by affirming that "this is paradise, and nothing can change it". As the credits roll, we witness a succession of images that contradict what he just said: dirty streets, ruined buildings, depressed homeless and inexpressive people walking in the streets.

The protagonist's comments about Cuba as The Land of Plenty evoke the origins of the myth of America as utopia. Since the Age of Discovery, cultural production in the New World has been marked by utopian ideals. America was soon seen as an empty space upon which Europeans projected their overflowing imagination. The Mexican historian Edmundo O'Gorman (1958) went so far as to affirm that in 1492, America was not discovered but "invented", alluding to the fantasies that the first explorations of the New World provoked in Western Europe (8). In fact, we cannot forget that Western utopian discourse was rationally structured around the phenomenon of the so-called discovery of America (Aínsa 2004, p. 30). At the beginning of the 16th century, Thomas More ([1516] 1963)'s Utopia was influenced by the early historical narratives of the discovery and conquest of America. Shortly after, a Franciscan bishop of Michoacán, Vasco de Quiroga, applied More's theories to the communities of the Tarascan Indians (Fuentes 1992, p. 140), thus beginning the double tradition of utopianism: the descriptive (typical of the literary field) and the experiential (based on radical social reforms). Juan's comments ("This is paradise, and nothing can change it") are ironic for a spectator who knows that Cuba is anything but paradise and that something is going to change it, most likely for the worse.

We see the zombies reemerge again in the person who seems to be the president of the CDR (Committees for the Defense of the Revolution) as he attacks his neighbors at a gathering. At that meeting, the attendants are alerted to a possible epidemic. Soon, the streets begin to fill with zombies in what State-controlled TV describes as a US-backed plot to overturn the government. ${ }^{6}$ Politics, therefore, does not escape satire. The film even mocks the health system, one of the prides of the Cuban revolution: when an elderly neighbor of the protagonist turns into the living dead, his wife attributes it "to the expired medications that are given at the polyclinic".

Juan de los muertos is a grotesque zombie comedy inspired by Edgar Wright's Shaun of the Dead. In fact, it is the first zombie movie made in Cuba and the first horror feature film in decades. As is usual in all films of this subgenre, Juan has both social commentary and pure horror. In an interview with the BBC, director Alejandro Brugués said that despite being clearly about zombies, it is also about Cubans and how they react to a crisis, because Cuba has faced many crises over the last 60 years (Jiménez 2012). Therefore, although the film masquerades as a gore explosion, much more awaits the viewers. 
Brugués takes his humor to emblematic settings in Havana, such as the Malecón, where a stampede of the undead takes place next to the United States Interests Section, or the Plaza de la Revolución, which is shown strewn with heads cut off by a fanatic gringo on a "religious trip". These settings are key to the success of the film. As Dean Luis Reyes (2012) points out, "the city of Havana reigns in this fable of adventures, whose best moments involve the creolization of the clichés of the genre [ . . ] Brugués managed to build a fluid story, where all the stereotypes of Cuba as a global symbol meet, privileging the mockery of the hyperbolic idiosyncrasy of the Cuban, as well as the legitimization of the resistant character that we have had to assume in the face of all kinds of catastrophes of history" [my translation].

Juan de los muertos ultimately reveals itself as transgressive, but in the postmodern sense of the term. There is no open political denunciation of one sign or another, nor does it respond to a specific ideology. Its political discourse remains within the "liquidity" (Bauman 2000), "liminality" (D'haen and Bertens 1994), and "ambiguity" (Eisenberg 2007) that distinguish postmodernism. It undermines types and stereotypes of national identity while using them to attract both the Cuban viewer and a transnational audience. It satirizes institutions and ideologies while giving up on proposing viable alternatives. The New Man of the socialist revolution is here transformed into a rogue whose only interest, at least initially, is personal gain, although the myth is taken up in the end after an unlikely transformation of the character.

The ambivalence of the film's message reaches its climax in the last sequence, where many of the ideas outlined above are subverted. When everything suggests that Juan and his friends are going to leave the country on a raft to Miami, Juan decides to stay on the island, fighting as a kind of suicidal guerrillero-something that must have pleased international audiences still enamored with an idealized view of Che Guevara. The final pose of the character seems to follow a return to the myth of national heroes involved in an endless war against an enemy. However, Juan is here a humanized hero, stripped of the messianic and quasi-religious aura of the revolutionary figures. Juan's leap over the zombie horde gives rise to a transformation of the "real" images of the film into a comic book where we see his friends reappear to join a battle that seems to parody films such as La primera carga al machete (The First Machete Charge, 1969). At one point, we have a glimpse of a cartoonish Fidel Castro, who seems to be leading the zombies. Yet, everything is presented in a frenetic and chaotic way against the soundtrack of the punk version of My Way that Sid Vicious created for the Sex Pistols and which is, in turn, a parody of the original that Paul Anka adapted for Frank Sinatra. In this labyrinth of parodic discourses and counter-discourses, of competing ideologies, and of transnational economic interests, we are left with the impression that the important thing for the characters is friendship and family - something that points to a distancing from the revolutionary metanarrative and that connects with an increasingly generalized trend among young Cuban filmmakers. As opposed to the official modes of citizenship embodied by abstractions such as "the People", "the Homeland", and the "New Man", Juan de los muertos seeks to rescue individuals in their context but also in their full singularity. In contrast with the solemnity of many classics of Cuban cinema, it turns satire and mockery into its fundamental critical tools.

\section{Landscapes after the Battle}

While Alejandro Brugués' film is pervaded by a raw, often vulgar, humor aimed at criticizing the difficult living conditions in Cuba today, in Los desastres de la guerra (The Disasters of War, 2012), Tomás Piard offers a solemn-at times pompous-denunciation of contemporary ecocide as a crime against humanity. Unlike Juan de los muertos, there is no reference here to the Cuban condition. Piard opts to present a universal problem for which he suggests vague solutions that have very little in common with those hinted at by Brugués. However, although the theme may be universal, the local nature (and lower budget) of Piard's film, which was made mostly for Cuban TV, contrasts with the transnational quality of Brugués' film; the result of a co-production with Spain and a 
film that had wide international distribution, as well as popular acclaim. The scarcity of resources in Los desastres translates into all sorts of technical problems that may be overlooked considering the audacity of the filmmaker, who was one of the very few Cuban directors to tackle environmental issues from an original perspective.

Tomás Piard was, in fact, a pioneer of post-apocalyptic film productions. His first film, Crónica del día agonizante (Chronicle of the Dying Day, 1966), made with his high-school friends, delved into the destiny of four characters living during the last day of life on Earth. This film was created during a time when there were rumors that neutron bombs were being made. In 1979, he filmed La espiral (The Spiral), related to another final war and the fate of its survivors. In 1997, in Spain, he shot Dies irae, a new apocalyptic version of the end of the world inspired by the Chernobyl disaster. In 2001, he made a co-production between Galicia, Switzerland, and Cuba, Finis terrae, inspired by the Soviet science-fiction art film Deadman's Letters, by Konstantin Lopushansky, which was screened only once at the University of Havana. La noche del juicio (The Night of the Trial, 2010) was the first part of a diptych on the possible end of life as a result of climate change, while Los desastres (the second part) would suggest the reaffirmation of life after death. Piard's long and strong interest in ecological matters, which are handled with a spiritual mindset, aligns his work with the ecocriticism of both the native tradition represented by José Martí's pantheism and the mystical attitude towards nature of the US transcendentalists. It is also akin to Lawrence Buell's concepts of the environmental text and of environmental apocalypticism, as outlined in The Environmental Imagination (Buell 1995). ${ }^{7}$

Los desastres takes place in a post-apocalyptic world. Seven survivors (a boy, four young men, and two adults) set out to sea-the great matrix of life-in search of a new evolutionary cycle. Apparently, none of them have seen the ocean before and no one knows what it is like, but they believe that the beginning of a new life could be achieved there. They march with faith, and the whole journey is an agonizing adventure, without food and without water. Injured, they only have each other. Led by a "Messiah" dressed in white, they are strangers who pretend to be like family, even though the devastation has been such that the term "family" is almost unknown among survivors. In their march, the pilgrims strive to restore the value of that institution as a social nucleus, which will allow them to not only transform their lives after being in contact with one another, but also to renew themselves and to recover the human condition that had been taken from them. ${ }^{8}$

A few flashbacks of life before the war offer a more visual reference to the past, but the catastrophe that caused this disaster is never directly identified. It is an ecocatastrophe, meaning that everything in the Earth's ecosphere is dying. The devastation has stripped humanity of everything nature used to provide, and humans have become a more animalistic version of themselves. Always at odds with one another, the survivors live in small packs or alone, in constant fear of others. They travel through a rough, inhospitable environment as they encounter thieves, gangs of cannibal tribes, and a few lone survivors. The characters remain in a state of total despair throughout the film, which is reflected in the long takes and minimalist dialogue. Regarding the almost total absence of dialogue, Piard declared in an interview: "I believe that when beings develop a spirituality, especially like that of the protagonist, words are unnecessary. And from that base it was that I built the script, using the text only when it was essential. My characters don't need to speak because they are in another dimension, hence a glance is sometimes enough to communicate with each other" (qtd. in Menéndez García 2012).

Los desastres demonstrates humanity in all its forms as it tries to survive. Animalistic behavior is a stark reminder of the extent to which humans will go for survival. It also suggests that morality is tied to culture and governance. The environmentally induced post-apocalypse narrative in the film poses the question of what humans would do when society fails to protect the environment. If the most integral part of humanity is nature, then failing to preserve it would represent humanity's end. Like in some of his previous films, Piard is reflecting on the turbulent reality in which we presently live-a reality that pushes us every day to do what may cause the end of our species or our planet. The erosion 
of the natural resources essential for existence, wars, and a general world crisis augur an end not far removed from what the Cuban filmmaker proposes in his film.

In their pilgrimage, the characters cling to a nebulous hope. Piard steers toward an allegorical path of fantastic tints, revealing a humanistic transcendentality in the main character, who is both a rude fighter and a Jesus-like figure. Finally, hope does not explode in a histrionic climax but in a restrained ending that is reminiscent of the style portrayed by Terrence Malick in The Tree of Life (2011). The last sequence displays a new Genesis of three Adams and three pubescent Eves who mysteriously appear at the end. An idea of divine predestination is given, reinforced by the main character's Messianic dimension; of a second chance granted by Providence to human beings, whose extermination was necessary to reset civilization on Earth. Piard does not go overboard on the lyrical aspects, opting instead for a finale of soft symbolism.

The film originates in a script written by Piard himself and is a co-production between the ICRT (The Cuban Institute of Radio and Television), the ICAIC (The Cuban Institute of Cinematographic Art and Industry), and the FAMCA (School of Audiovisual Communication Arts and Media). The title of the film is a direct reference to Goya's eponymous series of 82 prints created between 1810 and 1820 to protest against the violence of the 1808 Dos de Mayo Uprising during the Napoleonic invasion of Spain, which is considered to be one of the most significant anti-war works of art. The etchings detail the cruelties committed in the Spanish War of Independence, but they have come to achieve more universal overtones. Cruelty, fanaticism, terror, injustice, misery, death, etc., are the "fatal consequences" of war and political repression. Their severity is such that artists do not hide them behind anecdotal options and heroic portraits of particular individuals. The victim of the war is the collective man; that man, typified and anonymous, is both the subject of the actions and the recipient of the explicit message in the images.

Piard's film presents this topic in the form of a roman à these of mystical overtones, something very rare in Cuban cinema. Supported by the notion that man can only survive if he does not lose faith, the film exudes spirituality, showing us that, regardless of the conflicts, latently in each one of us, there is a creator of miracles. Los desastres advocates love in its broadest sense; love between men in a generic, unique, and true form of salvation that allows us to constantly reinvent ourselves. Parallel to the above, the film supports the premise of man's cruelty against himself and his loved ones-a visceral hatred that if allowed to grow would lead to the destruction of humanity as we know it. It also shows the most libidinous passions, taken to an extreme degree. Dehumanization, cruelty, hunger, and death are shown with the bloodiest savagery, caused by despair and, above all, by the loneliness and alienation of the subjects. Blood (abundant in many scenes) is thus opposed to the purifying water of the ocean and is the reason that the film has earned the reputation of being post-apocalyptic and violent.

The intention of symbolizing, condemning, and arguing against the war and its consequences is so evident, so militant, that the construction of the characters is sacrificed in pursuit of the message, instead of articulating and making their construction more complex based upon their relationships, attitudes, and diversity. Likewise, the production leaves much to be desired in terms of the actors' direction, and the little dialogue that is said is, at times, stereotyped and clichéd. According to Piard, the production of this film was a great challenge for the young team. The numerous special effects were difficult to achieve in many cases due to the shortage of technological equipment and the lack of a Cuban industry specialized in these tasks. Regarding dramatic progression, the film obtains a decent result, with well-thought-out turning points, realistic triggers, and an ending that demonstrates the director's thesis: life is always possible. There is, therefore, a utopian glimpse at the end when we witness what seems to be the promise of a new life cycle of spiritual overtones. ${ }^{9}$ 


\section{The Cuban Hunger Games}

Omega 3 (2014), by Eduardo del Llano, articulates its dramaturgy and mise en scène into a clear science-fiction affiliation. As Piard does in Los desastres, del Llano chooses to place his story in an imaginary future in which humans are not divided by nations or races but by their diet. The opposing sides include Cars (carnivores), Ollies (ovo-lactarians), Vegs (vegans), and Macs (macrobiotics). They are not fighting for world peace but for the imposition of a diet; hence the title of the film itself, which refers to certain fatty acids that are a highly important component in the proper functioning of the body.

Omega 3 was the first science fiction film produced by the ICAIC in Cuba. Other films with elements of science fiction preceded it, but they cannot be fully considered as science fiction. ${ }^{10}$ Some consider it to be a comedy, while others consider it a tragicomedy. Some place it within the tradition of "gourmet cinema", for the central role of food in the film; others describe it as cyberpunk, because of its mixing of technological development with a certain degree of disintegration or radical change in the social order. The director himself has classified it as speculative fiction because it takes certain phenomena from reality and transfers them to a different space-time dimension, but it can also be considered as a philosophical and existentialist reflection on dystopia (the antithesis of an ideal society).

Omega 3 is based on the eponymous story that del Llano wrote in 2010, although it was not published until 2016. The film adds situations and characters such as an Ollie named Ana who did not appear in the original story. The obsession with the subject of food comes from the contemporary Cuban context. Food shortages and the difficulty of accessing the basic elements of a healthy diet have been a problem in Cuba for a long time, especially since the Special Period. ${ }^{11}$ It is not only difficult to eat meat but also, paradoxically, to be a vegetarian. In addition, the delicacies that Officer Mac offers Ana and Nic in a restaurant are a juicy steak and a huge lobster-both inaccessible to most Cubans. Except for the paladares (private restaurants), Cubans can only buy these products on the black market. In the past, if someone was caught carrying and storing meat, they could be sentenced to several years in jail.

The idea of a macrobiotic evil "kingpin" is not accidental either. An important component of the macrobiotic diet is tofu (which the protagonists disparagingly refer to as disgusting), and tofu is made from soybeans. For decades, the Cuban State substituted meat with soy in many kinds of dishes-something that was not well received by the population. Soy and other "solutions" offered by the State to replace meat, milk, and yogurt, scarce in the market, were often mocked by Cubans.

Each group in Omega 3 claims its diet as the healthiest and supports the idea with scientific dogmas, in a similar way to how Cuba and the socialist bloc relied on MarxismLeninism to justify all kinds of beliefs. There does not seem to be much difference between the scientifically supported paternalism of the Macs, the Vegs, the Ollies, and that of the Cuban State. Omega 3 is therefore about tolerance and respect for different opinions, and it defends the right of everyone to enjoy what they like to consume.

The film had a very low budget, and its director worried about the locations, materials, and specialists. However, he found "strange talents dreaming of opportunities", like those offered by this film. They had to resolver (make do) using existing locations and recycled materials. ${ }^{12}$ Del Llano was also concerned that people would only see Omega 3 for its special effects and compare them to Hollywood sci-fi movies. In an interview (Acevedo 2014), he emphasized that the 42 shots with special effects were never intended to compete with the Hollywood blockbusters that usually have thousands of them.

Omega 3 is committed to narrative and theatrical minimalism by using a mise-enscène based on long dialogues between contrasting and contradictory beings, involuntarily reunited by confinement in a prison location, with little or no hope, except for mutual understanding and solidarity; in this case, the love between the soldier from the Veg faction and the Ollie police officer. Both are victimized and manipulated by a Kafkaesque hostile context that transcends them absolutely and leaves them with no possibility of escape, not even of understanding the circumstances that surround them, gestated by a third enemy, 
the Macs, who are led by an evil officer. This antagonist (the Mac officer) uses different tactics to destroy their dietary convictions and force them to participate in his experiment of seeing what happens when an Ollie and a Veg eat meat. This reaches its climax in the "torture" sequence, in which the Veg soldier and the Ollie officer are forced to consume meat at an elegant restaurant. The music they hear is a jazzy version of Silvio Rodríguez's "La tierra está pariendo un corazón" (The Era is Giving Birth to a Heart), which is ironic since this was one of the most iconic songs about international solidarity and the Guevarian myth of the New Man.

The film begins and ends with the story of a family: parents and their son, who does not want to eat his big steak with fries. The child is distracted by a crossword puzzle while he absent-mindedly listens to the television that promotes a healthy lifestyle, which serves as a contrast to the food that his parents want him to eat. The camera focuses on the child, but the parents are out of the frame. The viewer can only hear their voices ordering him to eat. Occasionally, the audience can see parts of their bodies in extreme close-ups. The final scene reveals that they are Nic and Ana, thus suggesting a continuous cycle of oppression. Ana and Nic, previously victimized, use the same persuasion strategies with their son as those used with them by the Mac officer.

\section{The Foggy Frontier between Reality and Fiction}

The most experimental trend in Cuban dystopian cinema is represented by Rafael Ramírez and Alejandro Alonso. Ramírez's short film, Diario de la niebla (2016), was inspired by Jorge Luis Borges' enigmatic and disturbing story “Tlön, Uqbar, Orbis Tertius", which proposes a puzzle that is equally fragmented and hazy, accordingly with its title. In just a few minutes, Ramírez anchors his eminently dystopian discourse and his mythological and philosophical intentions in pure Lovecraftian horror, suspense, post-apocalyptic science fiction, uchronia, and even espionage (Gonzalez Rojas 2016). All these elements are skillfully embedded in the subgenre of found footage, which even in its most commercial expression implies a blurring of the lines between the once clear fields of fiction and the documentary.

The protagonist, unknown even to himself as he suffers from a kind of post-traumatic amnesia that prevents him from knowing how he got to the place, films snippets of a hallucinatory decadent reality, which is completely alien to him, especially due to his clear status as a foreigner (someone who has just "landed"). Through his distorting lens, he scrutinizes the remains of a fateful civilization, entrenched in the imaginary city of Dzershinski, which appears to be besieged by a monstrous fog that has engulfed life for centuries. The city is populated by beings whose only purpose seems to be survival itself, although they are almost as ghostly as their nameless enemy, who they keep at bay with bizarre methods.

Ramírez marks the extreme oddity of his filmic account with black and white "dirty" photography. The city and its surroundings are presented as a world without sun, shown as grayish, eternally gloomy, and oppressive-as suffocating as the mental state of the lyrical protagonist, who prioritizes the use of inquisitive, transgressive, and almost clandestine extreme close-ups of individuals, documents, and objects in order to throw certain lights on the reality he depicts.

The protagonist's own confusion finds an equally suitable echo in twisted images, which could well be considered the outcome of delirium and hallucinatory emanations resulting from the unfolding of the mind in an alternate, virtual reality. The fragmentary and psychedelic nature of the story and its diegesis are also organically emphasized with an irregularly violent montage, whose capricious rhythm, rather than the lack of expertise of the common circumstantial investigator of found footage, refers once again to the frenzied loss of identity, abruptly transferred to an abnormal state of existence. However, the narration advances with optimal agility toward a disturbing climax of sheer terror, where a stentorian soundtrack bursts in, which seems to have waited, crouching throughout the entire footage, disguised in its shadows and ghosts. As the film ends, a roar of Tibetan horns 
seems to scatter through the remnants of Dzershinski with the same inhuman brutality as the fog itself.

The basic anecdote of Diario comes to constitute a mere piece of Ariadne's thread that, in the form of discrete signs scattered throughout the story, invites us to retrace its initial nucleus toward much larger labyrinthine spheres that rotate concentrically, or of which the history of yore is hardly a tangential skirmish. Its infinitesimally filtered subplot suggests an infinitely more complex cosmogony, where the Bahamut Limited Corporation and Dr. James Cracker Fishbourne, referred to as the owners and publishers of the material, conceive alternative worlds. As Dean Luis Reyes (2017b) suggests: "Ramírez invokes two central repertoires of the documentary tradition: the use of the archive, found footage, and scientific inquiry, the discourse of authority, present in much of the conventional expository documentary. He invokes them to subvert them. He places us, as viewers, in a new terrain for fiction. What's more, he puts the documentary's very instruments in the pillory by revealing its existence as fictive propaganda based on real events".

Rafael Ramírez is a creator whose poetics do not subscribe to the Cuban film canon. Among all the filmmakers discussed in this essay, he is the only one who seems entirely indifferent to national or social concerns. The more direct references in his films must be located in the world of speculative fiction. In this sense, Diario is closer to the philosophical views of Borges and to the insane imagery of Lovecraft than to Cuban cinema's political concerns. From Borges' most metaphysical fictions, he takes the exploration of possible worlds, with their own rules and their own systems of intellection (religion, philosophy, science, literature) that emerge from our own reality. He also resorts to Chinese-box structures and narrative metalepsis to foreground "the ontological dimension of recursive embedding" (McHale 2001, p. 120). From Lovecraft, he adopts his anti-humanistic "cosmicism" (the negation of any divine presence in the universe and the consideration of humanity as an insignificant speck in the grand scheme of space and time), as well as the use of a non-omniscient narrator who tends to abound in detail, especially in the descriptions, while silencing crucial elements to generate tension or expectation through ellipsis. The mood of this short film is equally gloomy and menacing, and the major conflict revolves around the inability of the human mind to deal with an incomprehensible, alien evil. The list of analogies with the literary worlds of Borges and Lovecraft could be almost endless, but it is immediately clear when we watch Diario de la niebla that its referents are not in the national film tradition but in speculative world fiction.

\section{The Citrus Tristeza Virus}

In El proyecto (The Project, 2017), Alejandro Alonso returns to a theme that had gained relevance two years earlier with Machado Quintela's La obra del siglo: the political and architectural megaprojects of Cuban socialism in the 1970s; in this case, the Basic Secondary Farm Schools (ESBEC) and the Preuniversity Farming and Academic Institutes (IPUEC). ${ }^{13}$ Both served to showcase the revolutionary project internationally, which explains why several of these constructions were destined for the training of foreign students. The director himself was part of that project, stating:

I was part of the Farm Schools experiment. I was one more actor in the attempt to create the New Man, as were my parents. In Pinar del Río, where I was born and raised, there is one of the largest structures of this type, with more than 20 schools: Troncoso. There are large fields planted with oranges, a crop around which all the study-work activity of those places revolved. I spent three years of my life in that place, which were very complex for me. Even military service was not as difficult as that period. I still have the trauma of that experience, and I have very clear memories of the relationship with the space and with those great structures where I lived. There was something there that needed to be resolved [my translation]. (Reyes 2017a)

In the so-called Special Period (1991-1994), when Cuba's GDP contracted 36\% due to the inability to cope with the dissolution of the USSR and the tightening of the US embargo, 
most of the ESBEC and IPUEC stopped working. In 2009, these rural schools started to close, then becoming shelters for needy peasant families as a kind of reinvention of the initial program now transformed into agricultural communities. However, most were not given the necessary tools or construction materials, and that project also failed.

To make his film, Alonso visited 16 schools, as well as some communities that were better developed in terms of infrastructure. They had received a great deal of support from the government, although they could not work the land: "Once again, nature rebelled and dictated what to do. That idea of the land that rebels against all kinds of utopia captivated me. I learned about the Citrus tristeza virus disease, and this became the focus of the film, which was also going to serve as my title. The Citrus tristeza virus is a small vector that gets into citrus and ends up killing it. After that, the land cannot be sown for several years [my translation]" (Reyes 2017b).

El proyecto began production in one of those dilapidated facilities. It included photographs, plans, graphic materials, and a voice recording that showed the relationship between what was left of the architectural and the educational project. Fragmentation in the film was a way of expressing in language what had happened to utopia. However, filming was suspended, and Alonso was forbidden to continue. In this way, the film became a truncated project about a failed one, which contributes to what could be considered an extreme form of reflexivity that is highly unusual in documentary filmmaking. Thus, in this work, the interest in the sensory coincides with questions that the filmmaker asks in the film's abundant subtitles, which work as a kind of voiceover about the director's relationship with those he films - the construction of the "other" and the location from which Alonso tells his story. The film's most significant shot is one that portrays a distorted photo which seems to represent another observer trapped between disjointed lines. All this is accompanied by a fictional subplot that is built from another historical fact: the detection in the 1990s of the above-mentioned Citrus tristeza virus in Cuba.

El Proyecto stages the passage of time and its impact on the crumbling ruins where grass has reclaimed its space. In this sense, Ramírez seems to re-envision the tragic spirit of Romanticism with a postmodern twist. Like in José María Heredia's poems, Caspar David Friedrich's paintings, or Giovanni Battista Piranesi's etchings, in El Proyecto, we witness the destructive power of nature. Ramírez depicts ruins with an angle of terribilità; never smooth but covered with moss and brush, never sharp and outlined but cracked, twisted, and tortuous. However, unlike the Romantic contemplation of ruins, which are pervaded by a feeling of nostalgia, the collapsing architectures of El Proyecto bring memories of vanity, deceit, and repression. We see large concrete structures with dark and gloomy corridors that are now traversed by new lives that express themselves dancing and that do not face the camera until the very end. Furthermore, the combination of futuristic architectural plans, audio clips that reveal the scale of the project, and the ideal of this New Man, mixed with characters who fumigate the old citrus fields, give an eerie, apocalyptic tone to the film.

Like Ramírez employed in Diario, Alonso uses a post-apocalyptic background to invoke two main tenets of the documentary tradition: the use of the archive (found footage) and the scientific inquiry (the discourse of authority), which are present in conventional expository documentaries, only to subvert them, thus posing questions about the subjective nature of reality.

\section{The Fall of the New Man}

Corazón azul (2021), Miguel Coyula's most recent film, is an ideal compilation of most of the trends I have been discussing in Cuban dystopian cinema. It is also an ideal synthesis of Coyula's recurring obsessions and creative strategies: the postmodern aftertaste for pastiche, the interweaving of the style of comics, dystopian worlds, and B movies, the construction of characters that are psychologically dislocated and tormented by a hallucinatory reality from which they try to escape, and the creation of sordid, gothic atmospheres. In Coyula's films, these codes do not serve a formalist purpose but have a political intent, no matter how explicit that may be. This is a director who has tried to 
respond to a world that increasingly oppresses individual freedom. His dystopian universes are the way to expose through film what he perceives in a reality veiled by ideologies.

Corazón azul submerges us in a uchronic Cuba through the recovery of science fiction topics that allow us to trace a retro-futurist reflection on the contemporary state of the country. Through the author's characteristic visual imagery and an atmosphere of uncertainty, chaos, insecurity, and perennial violence, Coyula speculates about a nation collapsed by the nightmare unleashed by a totalitarian government which confines daily life to the condition of a residue.

The protagonists are a group of young mutants with superhuman powers who live on the fringes of society, in radical opposition to the country's political forces. They are the result of a genetic engineering project called the "the Guevara experiment" and promoted by Fidel Castro with the aim of improving humans-a metaphor for the construction of the New Man—and thus saving utopia.

Numerous intertextual references, modified documentary inserts, and reflexive tricks populate the fragmented narrative that mingles reality and fiction. As Patricia Boero (2021) points out in her review of Corazón azul, "the film mixes genres and styles, from science fiction to wartime newsreels, expressionist design, melodramatic acting and surrealist references, all serving an elliptical, anarchical narrative that propels the film into unexpected twists and turns. The signs and signals that appear in the film are familiar to anyone with some knowledge of Cuban history, yet also have universal meaning in their portrayal of any authoritarian regime".

There is an irreverent rendering of revolutionary icons (Fidel Castro addressing the masses; Korda's photo of Che Guevara) and deconstruction of political slogans. Former American presidents Barack Obama and Donald Trump and current Cuban leader Díaz Canel make cameo appearances, sometimes using archival footage and other times through manipulated statements. A Cuban TV anchor provides Brechtian commentaries of the action on screen. He tells us that the genetic experiments have produced failed mutants who have escaped government control. The failure of the experiment-an allegory, in turn, of the failure of the revolutionary project itself-condemns these people to a hidden life controlled by higher powers that suppress any type of freedom in them.

History navigates within the frameworks of the confrontation between these individuals (they have organized themselves into a kind of resistance group) against the government that intends to keep them on the peripheries of society, hidden from the eyes of the world. At the same time, there is also a journey of personal redemption. Elena, who is among the protagonists, must face the consequences of discovering the identity of her father. In an environment of total axiological imbalance and a desperate search for identity, these beings, who are the children of failure, try to uncover a regime that has kept reality in check so that they can save themselves.

To enhance the apocalyptic nature of his film, Coyula uses suggestive settings such as the abandoned nuclear power plant near the city of Cienfuegos (formerly a memorable set of La obra del siglo by Carlos Quintela) and the Havana Art Institute (Instituto Superior de Arte), with domes in brick and circular courtyards. Everything in Havana that is the background to the story is deadly and ghostly, with chimneys that spit fire and vultures that circle in the sky. These symbols of decadence and environmental degradation become a leitmotiv throughout Corazón azul; they are the background of a story that, as recalled by Patricia Boero (2021), "deepens the meanings of identity, belonging, and the existential choice between conformity and rebellion".

Coyula's point of view reveals itself only by the end, within a narrative riddled with gaps and ambiguities. In the last scene, the character named Case \#1 tells Elena that "it doesn't matter who our parents are, the important thing is who we are". Like a question mark, this idea runs through the entire discourse of the film. 


\section{Conclusions: The Ruins of Utopia}

The body of dystopian works studied demonstrate the diversity present in the Cuban cinemascape. In recent years, we have witnessed a growing broadening of both its formal repertoire and its content. As a result, multiple forms of expression have proliferated within the sub-genre of post-apocalyptic dystopias: from the grotesque comedy Juan de los muertos to the solemn film à thèse Los desastres de la Guerra, and from staged theatricality in Omega 3 and Eternal Glory to the postmodern performances of Diario de la niebla and El proyecto. The recent film Corazón azul assembles many of these trends among dystopian fictions in an apotheosis of hybridity that originates in Coyula's penchant for postmodern pastiche and cinematographic collage.

These films address the failures of the revolutionary project and Cuba's dystopian present in diverse ways and through different approaches. All of them interpret the current state of the nation as dysfunctional. As in the literary fictions of the last decades, a clear displacement can be observed between the two semantic poles of the concept of utopia. While in its origins, the revolutionary project was contemplated in national cinema within the utopian realm of the "good place", in the early 1990s, it began to be displaced toward a "no place", precisely because of the loss of faith in utopian discourse. More recently, pessimism advances through dystopian Cuban cinema in a crescendo of desolation and helplessness originating in the subjects' inability to cope with the anomalous circumstances that surround their existence and that completely cut off their own human individuality.

In all these cases, ruins act as a metaphor for the collapsing metanarratives of the Cuban revolution. Although there is at times a literal and genuine concern for environmental issues, the image of ruin is used here rather to reflect upon the downfall of utopia. In contrast to the rigid, exclusive, and homogenizing impulse of revolutionary discourse, these films propose a more fluid, inclusive, and porous view of Cuba's condition-one that is exhibited by a series of paradigm shifts regarding debates on national identity, from nationhood to personhood, from citizenship to sentiment, and from utopian to dystopian narratives of space.

Funding: This research received no external funding.

Conflicts of Interest: The author declares no conflict of interest.

\section{Notes}

1 For the concept of "speculative fiction", I follow Esther L. Jones (2006)'s definition: "Speculative fiction is a cover term for a diverse range of genres, linked by their utilization of nonrealist narrative strategies. This includes science fiction, fantasy, horror, utopian fiction, futuristic fiction, alternate histories, and other forms of literature that employ literary devices, strategies, and/or settings that diverge from the empirical reality that mimetic fiction uses as its foundation".

2 The most comprehensive and widely disseminated monograph on Cuban cinema (Chanan 2004) does not cover the 21st century and overlooks the few precedents of speculative cinema in Cuba. As in all his studies, Chanan adopts an acritical and apologetic view of the Cuban revolution and of its cultural production that has been recently contested by a younger generation of critics in Cuba and abroad. Anne Marie Stock (2009)'s On Location in Cuba: Street Filmmaking in a Time of Transition offers a more detailed and persuasive exploration of recent films, although the focus of her book is rather on the emergence of an entrepeneurial approach to art production among recent filmmakers. The most interesting analyses of Cuban distopian cinema come from young Cuban critics, such as Dean Luis Reyes and Antonio Enrique Gonzalez Rojas, whose articles appeared in cultural magazines and internet blogs and who are being quoted in this essay.

3 As Duanel Díaz (2014) suggests, "while the utopian project of the sixties was imagined as a construction (of socialism and communism, of the New Man), in this 'new era' the reference par excellence is the ruin" (2002). For an analysis of the role of ruins in Cuban contemporary documentaries, see Juan-Navarro (2020).

$4 \quad$ In this sense, Antonio José Ponte has pointed out the following: "when you visit Havana or think of Havana, you are not only traveling, thinking, visiting the ruins of Havana, but you are also visiting the ruins of Utopia, the city that was going to be, that was made of all of Marxism's hopes and that the ideology of the revolution had conceived for Cuban society" [my translation] (Morejón Arnaiz and Palmero González 2020).

$5 \quad$ Eljaiek-Rodríguez (2015) has explored how the apocalyptic subplot in the film is expressed even by the names of the characters themselves: "Juan—author of the Revelation and biblical figure who witnesses the end of time, Lazarus—the resurrected par excellence of Christianity and the dead who walks again among the living, and Vladi-possible contraction for Vladimir, but also 
Vlad Tepes, the historical character that Bram Stoker used to model his Gothic version of the not dead. Vladi California-the full name of the character-is also an incarnation and mockery of the historic struggle between Cuba and the United States" (p. 87).

6 The way official media refer to the zombie plague is the same that the Cuban regime has always used to stigmatize social protests in Cuba. Thus, the recent demonstrations of July 2021 in various towns and cities on the island were also associated with the old discrepancies between Cuba and the United States, and the organizers of the protests were described as "criminals" and "mercenaries" who promoted violence and vandalism.

7 Lawrence Buell defines three criteria for an environmental text: (1) the non-human environment is present not merely as a framing device but as a presence that begins to suggest that human history is implicated in natural history; (2) the human interest is not understood to be the only legitimate interest; and (3) human accountability to the environment is part of the text's ethical orientation. In chapter 9 of his book, Buell explores visions of environmental catastrophe in connection with the apocalyptic thought. For Buell (1995, p. 285) "Apocalypse is the single most powerful master metaphor that the contemporary environmental imagination has at its disposal".

8 The socialist Cuban regime has traditionally drawn on the image of the State as a family. Mesa Cumbrera et al. (2021) have studied these metonymic flows between the State and family in Cuba. In contrast to that hegemonic view, the social role of the family in the consolidation of Cuban civil society has been one of the leitmotifs of Piard's film production. As Valdés Paz (2005, p. 111) suggests, since the Special Period, "family became increasingly important to the population as a source of daily sustenance, solidarity, and resources, and to the State, which finally recognized it as an essential public policy link and an irreplaceable foundation of socialization".

9 As M. Keith Booker (2013, p. vii) points out in his introduction to Dystopia, "even the darkest dystopian fiction contains certain utopian energies, if only because the very motivation behind dystopian fiction is so often an attempt to provide satirical, cautionary warnings that might help us to prevent the undesirable events depicted in the fictions".

10 They include La vida en rosa (Life in Rose-Colored Glasses, 1988) by Rolando Díaz; Sueño tropical (Tropical Dream, 1993) by Miguel Torres; Madrigal (2005) by Fernando Pérez, whose script was written by Del Llano; and the already studied Los desastres de la guerra (The Disasters of War, 2012) by Tomás Piard. Apart from the characteristic framework of science fiction, it is difficult to determine any other generic affiliation.

11 The 1990s in Cuba is known as the "Special Period in times of peace"- a particularly hard time for the Cuban economy that led to a generalized impoverishment of the population. After the fall of the Soviet Union in December 1991 and its main economic and political partners, Cuba was forced into a precarious economic existence. The name Special Period is therefore a euphemism for defining the atypical nature of an economy isolated from the rest of the world. The negative effects of the new economic order were attempted to be covered up with a political campaign that tried to justify austerity measures such as the rationing of food and oil. Sectors such as agriculture, transportation, and energy suffered especially from the rigors of isolation. The regime took several measures to recover the economy, such as opening the island to foreign tourism, the legalization of remittances sent by Cubans residing abroad, the partial liberation of the agricultural market, and self-employment.

"Resolver" can be roughly translated as "to figure it out". It describes Cuban's ethos of tenacity in the face of adversity.

For many years, these projects became a priority for Castro's regime. The idea originates from the Commander-in-Chief himself, who was inspired by José Martí's statement that a child should "handle the notebook in the morning and the hoe in the evening" (Cheng and Manning 2003, p. 362). This is how the New Man would be created. They even found an anthem in Silvio Rodríguez's song "The New School", which starts with these lines: "This is the new school/This is the new house/New home and school/As cradle of new breed".

\section{References}

Acevedo, Ricardo. 2014. Omega 3: Ciencia Ficción fílmica ... a la cubana (Entrevista a su director Eduardo del Llano) por José Miguel "Yoss" Sánchez. Amazing Stories, October 3. Available online: https://amazingstories.com/2014/10/omega-3-ciencia-ficcionfilmica-la-cubana-entrevista-su-director-eduardo-del-llano-por-jose-miguel-yoss-sanchez/ (accessed on 17 November 2021).

Aínsa, Fernando. 2004. Utopias contemporáneas de America latina. Cahiers du CRICCAL 32: 9-33.

Bauman, Zygmunt. 2000. Liquid Modernity. Cambridge: Polity P.

Boero, Patricia. 2021. Corazón Azul. The Film Verdict. Available online: https://thefilmverdict.com/2021/10/01/blue-heart/ (accessed on 17 November 2021).

Booker, M. Keith, ed. 2013. Dystopia. Ipswich: Salem Press.

Buell, Lawrence. 1995. The Environmental Imagination: Thoreau, Nature Writing and the Formation of American Culture. Cambridge: Harvard UP.

Cardentey Levin, Antonio. 2014. La Revolución zombificada: La alegoría del trauma cubano en Juan de los Muertos, de Alejandro Brugués. Alambique 2. [CrossRef]

Chanan, Michael. 2004. Cuban Cinema. Minneapolis: U of Minnesota P.

Cheng, Yinghong, and Patrick Manning. 2003. Revolution in Education: China and Cuba in Global Context, 1957-76. Journal of World History 14: 359-91. [CrossRef]

D’haen, Theo, and Hans Bertens. 1994. Liminal Postmodernisms: The Postmodern, the (Post) Colonial, and the (Post-)Feminist. Edited by Theo D'haen and Hans Bertens. Amsterdam: Rodopi. 
Díaz, Duanel. 2014. La Revolución Congelada. Dialécticas del Castrismo. Madrid: Verbum.

Eisenberg, Eric M. 2007. Strategic Ambiguities: Essays on Communication, Organization and Identity. Thousand Oaks: Sage Publications.

Eljaiek-Rodríguez, Gabriel. 2015. El retorno de los muertos vivientes (al Caribe). Juan de los muertos y los zombis en el cine cubano contemporáneo. Hispanic Research Journal 16: 86-102. [CrossRef]

Fuentes, Carlos. 1992. The Buried Mirror: Reflections on Spain and the New World. New York: Houghton Mifflin Co.

Gonzalez Rojas, Antonio Enrique. 2016. Un diario lleno de sonido y niebla. IPS Cuba, September 2. Available online: https: / / www.ipscuba.net/sin-categoria/un-diario-lleno-de-sonido-y-niebla / (accessed on 17 November 2021).

Gustafsson, Jan. 2014. Entre el buen lugar y el no-lugar. Utopía, memoria y migración en la Cuba revolucionaria. Meridional. Revista Chilena de Estudios Latinoamericanos 3: 153-74.

Jiménez, Jesús. 2012. Juan de los muertos, la primera película independiente autorizada por el gobierno cubano. Rtve.es, December 1. Available online: https:/ / www.rtve.es/noticias/20120112/juan-muertos-primera-pelicula-independiente-autorizada-gobiernocubano/483423.shtml (accessed on 17 November 2021).

Jones, Esther L. 2006. Speculative Fiction. Oxford Bibliographies, June 29. [CrossRef]

Juan-Navarro, Santiago. 2020. La estética del derrumbe en el documental cubano contemporáneo. Delaware Review of Latin American Studies 18. Available online: https://udspace.udel.edu/handle/19716/27431 (accessed on 17 November 2021).

McHale, Brian. 2001. Postmodernism Fiction. London: Routledge.

Menéndez García, Yerisleydys. 2012. Sí, después de la guerra, existe el amor. El Caimán Barbudo, October 3.

Merleau-Ponty, Maurice. 1969. Humanism and Terror: An Essay on the Communist Problem. Translated by John O'Neill. Boston: Beacon P.

Mesa Cumbrera, Osmara, Lázara Yolanda Carrazana Fuentes, Dialvys Rodriguez Hernandez, Martin Holbraad, Isabel Reyes Mora, and María Regina Cano Orúe. 2021. State and Life in Cuba: Calibrating Ideals and Realities in a State-Socialist System for Food Provision. Social Anthropology 28: 803-26. [CrossRef]

More, Thomas. 1963. Utopía. London: Penguin Books. First published 1516.

Morejón Arnaiz, Idalia, and Elena Palmero González. 2020. La escritura de Antonio José Ponte: Entre las ruinas y el humor. XI Congreso Brasileño de Hispanistas. YouTube, September 20. Available online: https:/ / youtu.be/7szNrNMWb9o (accessed on 17 November 2021).

O'Gorman, Edmundo. 1958. La Invención de América. Investigación Acerca de la Estructura Histórica del Nuevo Mundo y del Sentido de su Devenir. México City: Fondo de Cultura Económica.

Reyes, Dean Luis. 2012. Legitimando la incorrección. IPS Cuba, May 25. Available online: https://www.ipscuba.net/sin-categoria/ legitimando-la-incorreccion/ (accessed on 17 November 2021).

Reyes, Dean Luis. 2017a. Conversando entre las ruinas. OnCuba News, April 17. Available online: https:/ / oncubanews.com/opinion/ columnas/republica-de-imagenes/conversando-entre-las-ruinas/ (accessed on 17 November 2021).

Reyes, Dean Luis. 2017b. Una movida de la no ficción. OnCuba News, November 23. Available online: https:/ / oncubanews.com/ opinion/columnas/republica-de-imagenes/una-movida-la-no-ficcion/ (accessed on 17 November 2021).

Stock, Ann Marie. 2009. On Location in Cuba: Street Filmmaking during Times of Transition. Chapel Hill: The U of North Carolina P.

Valdés Paz, Juan. 2005. Cuba in the Special Period: From Equality to Equity. In Changes in Cuban Society Since the Nineties. Edited by Joseph S. Tulchin, Lilian Bobea, Mayra P. Espina Prieto and Rafael Hernández. Washington, DC: Woodrow Wilson International Center for Scholars, pp. 103-22. 